\title{
PRODUCTION AND OPTIMIZATION OF LIPASE FROM Bacillus tequilensis NRRL B-41771
}

\section{KALYANA CHAKRAVARTHY BONALA AND LAKSHMI NARASU MANGAMOORI*}

Centre for Biotechnology, Institute of Science and Technology, Jawaharlal Nehru Technological University Hyderabad, Hyderabad-500085, AP, India.

${ }^{*}$ Corresponding Author: Email- mangamoori@gmail.com

Received: May 23, 2012; Accepted: June 18, 2012

\begin{abstract}
Extra cellular lipase production by the bacterial strain, Bacillus tequilensis was investigated in submerged shake flask fermentation. This work was intended to optimize culture conditions of Lipase production Bacillus tequilensis with submerged fermentation using $1 \%$ $(\mathrm{w} / \mathrm{v})$ carbon source, Nitrogen source and different oils along with physical parameters like $\mathrm{pH}$, temperature, inoculum concentration, agitation speed. The optimum pH and temperature for Lipase production in submerged fermentation were found to be 7.0 and $30^{\circ} \mathrm{C}$. Maximum activity was observed with $1 \%$ inoculum concentration, at incubation period of $48 \mathrm{hrs}$ and agitation speed of $200 \mathrm{rpm}$.
\end{abstract}

Key words- Extra cellular Lipase, Bacillus tequilensis

Citation: Kalyana Chakravarthy Bonala and Lakshmi Narasu Mangamoori (2012) Production and Optimization of Lipase from Bacillus tequilensis NRRL B-41771. International Journal of Biotechnology Applications, ISSN: 0975-2943 \& E-ISSN: 0975-9123, Volume 4, Issue 1, pp.134-136.

Copyright: Copyright@2012 Kalyana Chakravarthy Bonala and Lakshmi Narasu Mangamoori This is an open-access article distributed under the terms of the Creative Commons Attribution License, which permits unrestricted use, distribution, and reproduction in any medium, provided the original author and source are credited.

\section{Introduction}

Enzyme mediated processes have been under usage from ancient times, out of approximately 4000 known enzymes about 200 enzymes are of commercial usage. Majority of these enzymes are microbial in origin, with the advancement of technology, and wide application of these enzymes, many enzymes are brought in to use by various industries [1].

Lipases (E.C.3.1.1.3) are a group of hydrolytic enzymes that catalyze the degradation of triacylglycerols to diacylglycerol, monoacylglycerol, fatty acids and glycerols at the interface between aqueous and the lipid phase [2-3]. They are widely sread in nature, they were isolated from different source such as plants animals and microorganisms, Lipase have immense potential application in various industries like cosmetic, food, detergent, paper and pharmaceutical industries [4-7].Enantiomers of lipase are used for resolution of chiral drugs, Biofuels, personal products and flavour enhancers [8].

\section{Material and Methods}

Microorganism- Bacillus tequilenses strain was isolated from oil mill waste. The organism was identified on the basis of morphological and biochemical analysis following Bergey's manual of determination of bacteriology.
Qualitative assay- The ability of Bacillus sp to produce lipase was tested in tributyrin agar medium containing tributyrin oil $1 \%$ ( w/v). The $\mathrm{pH}$ was maintained at 7 . Lipolytic activity of Bacillus strain was determined by measure in the diameter of hydrolytic zones around each colony [9].
Lipase assay
The hydrolytic activity was tested by titrimetric method as de- scribed in (ACS Specifications, 1993) with slight modifications [10- 12]. $20 \mathrm{mM}$ Phosphate buffer, Arabic gum $(1 \% \mathrm{w} / \mathrm{v})$ and the sub- strate (olive oil) 1:1 (v/v) were made up to a total volume of $10 \mathrm{ml}$. The reaction cocktail was thoroughly mixed and equilibrated at $20^{\circ} \mathrm{C}$ and $1 \mathrm{~mL}$ of crude enzyme was added after being previous- ly incubated at the same temperature. The reaction was left at room temperature for exactly $30 \mathrm{~min}$ and stopped by adding $3 \mathrm{~mL}$ of $95 \%$ ethanol. The released fatty acids from oil substrate during enzymatic hydrolysis were titrated to neutralization with $50 \mathrm{mM}$ $\mathrm{NaOH}$ in the presence of thymolphtalein as an indicator. A blank was prepared for each sample, where the enzyme was inactivated by heating at $95^{\circ} \mathrm{C}$ for 15 minutes.
One unit of lipase activity was expressed as micro equivalents of fatty acid released from a triglyceride in $30 \mathrm{~min}$ at $\mathrm{pH} 7.0$ at $20^{\circ} \mathrm{C}$. 
Optimization of Medium Components for Lipase Production

The optimizations of the following parameters were done for the production medium and they are checked for the lipase activity.

\section{Incubation Period}

Bacillus tequilensis was grown in Tribuytrin broth containing yeast extract, $\mathrm{NaCl}$, peptone and $1 \%(\mathrm{w} / \mathrm{v})$ olive oil at $36^{\circ} \mathrm{C}$ in an in orbital shaker at an agitation speed of 200rpm. The culture broth was harvested at $8 \mathrm{~h}$ intervals by centrifugation at $8,000 \mathrm{~g}$ for 20 min at $4^{\circ} \mathrm{C}$. Supernatant was collected and used as crude enzyme solution. It was assayed for lipase activity.

\section{$\mathrm{pH}$}

To check the effect of $\mathrm{pH}$ on the production of enzyme, fermentation was carried out at different $\mathrm{pH}$ ranging from 3 to 10 with an interval of 1 and the lipase activity was assayed.

\section{Temperature}

To study the temperature optima of enzyme production, the fermentation was carried out at different temperatures $20^{\circ} \mathrm{C}, 25^{\circ} \mathrm{C}$, $30^{\circ} \mathrm{C}, 35^{\circ} \mathrm{C}$, and $40^{\circ} \mathrm{C}$ with an interval of $5^{\circ} \mathrm{C}$ for $12 \mathrm{hrs}$. The enzyme extracted from these cultures was assayed to check the activity.

\section{Agitation Speed}

To evaluate the impact of agitation speed on lipase production by Bacillus tequilensis, experiments was carried out at different agitation speeds ranging from 120 to $180 \mathrm{rpm}$ at $30^{\circ} \mathrm{C}$, pH of 7.0 with $1 \%(\mathrm{v} / \mathrm{v})$ of inoculum. The cultures were incubated for $48 \mathrm{~h}$ and the lipase production was studied.

\section{Different Carbon Source}

To determine the effect of carbon source on lipase production by Bacillus tequilensis, carbon sources mainly carbohydrates were screened for their efficiency to support lipase production like Glucose, sucrose, maltose, lactose, starch were used as the basal carbon source in basal medium and was assayed to check for the lipase activity.

\section{Different Nitrogen Sources}

Optimization was carried out by using different organic nitrogen as nitrogen sources. Different nitrogen source used were tryptone, Ammonium sulphate, beef extract, yeast extract, Soya bean Meal and various combinations of them as nitrogen sources. and was assayed to check for the lipase activity

\section{Results and Discussion}

\section{Qualitative assay}

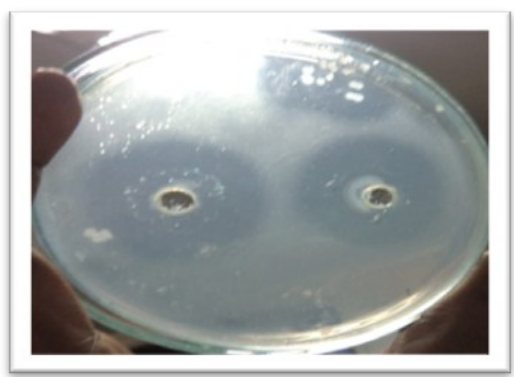

Fig. 1- Hydrolytic activity on tributyrin agar plate

\section{Growth Vs. Enzyme activity}

Bacillus tequilensis was cultured in $250 \mathrm{ml}$ Erlenmeyer flasks containing $100 \mathrm{ml}$ of medium at $30^{\circ} \mathrm{C}$ on in orbital shaker. The growth of the culture and lipase activity was monitored at a regular time interval of $4 \mathrm{hrs}$.

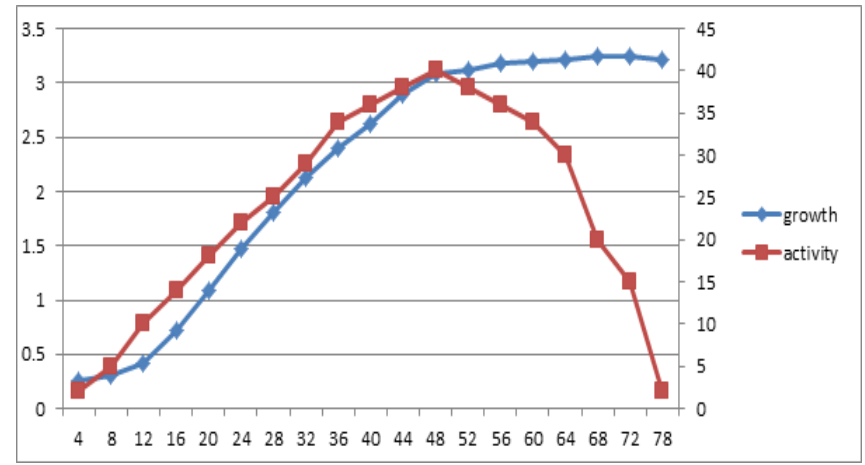

Fig. 2- Maximum enzyme activity of $4 \mathrm{U} / \mathrm{ml}$ was obtained at the end of log phase (48 hrs incubation period). After $48 \mathrm{hrs}$ of incubation, the Bacillus tequilensis entered the stationary phase and a decrease in enzyme activity was observed

Effect of different pH on extracellular lipase by solid submerged fermentation using Bacillus tequilensis

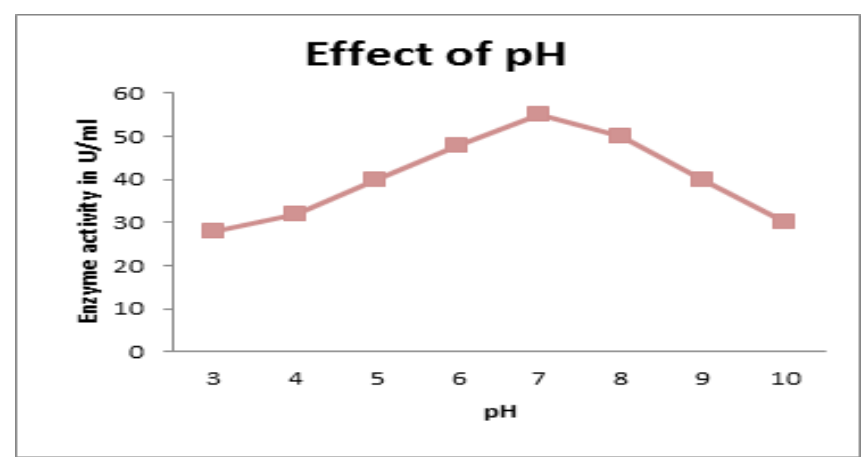

Fig. 3- Assay of the Lipase activity at different $\mathrm{pH}$ values within the range of 3-10 was done maximum activity was observed at $\mathrm{pH}$ 7.0 more than $80 \%$ of activity was observed at $\mathrm{pH}$ has indicated 7.0 as the optimum $\mathrm{pH} 6.0$ to 8.0

Effect of different Temperature on extracellular lipase by solid submerged fermentation using Bacillus tequilensis

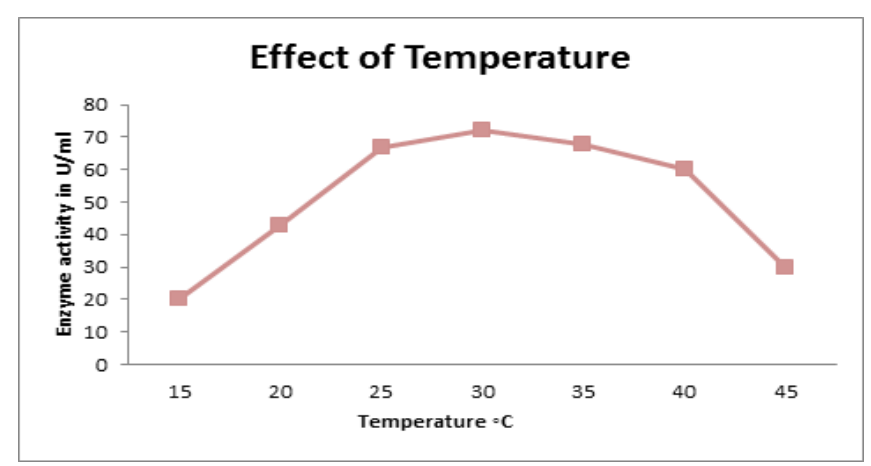

Fig. 4- Assay of was Lipase activity at different temperatures within the range of $15-45^{\circ} \mathrm{C}$ was carried has indicated $30^{\circ} \mathrm{C}$ as the optimum temperature. 
Effect of different Agitation Speed on extracellular lipase by solid submerged fermentation using Bacillus tequilensis

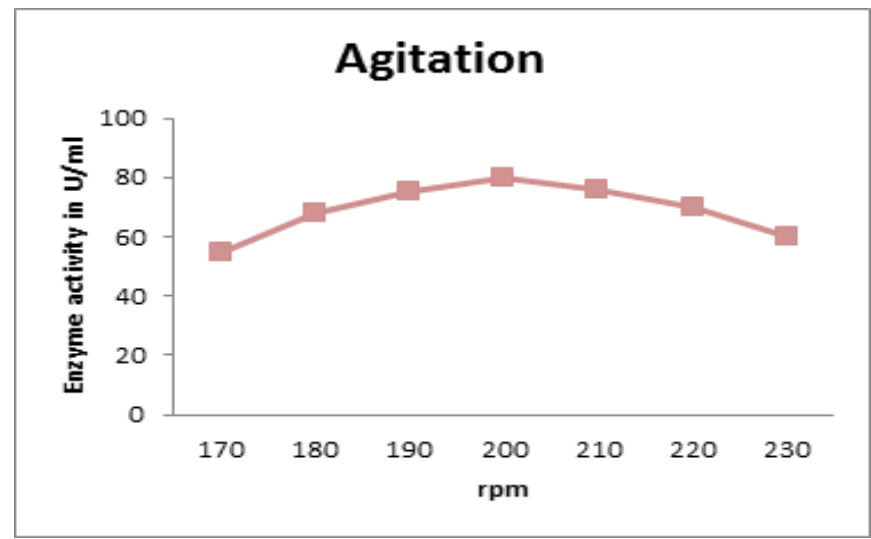

Fig. 5- Assay of the Lipase activity at different Agitation Speed within the range of $170-230$ has indicated 200 as the optimum Agitation Speed

Effect of different Carbon Source on extracellular lipase by solid submerged fermentation using Bacillus tequilensis

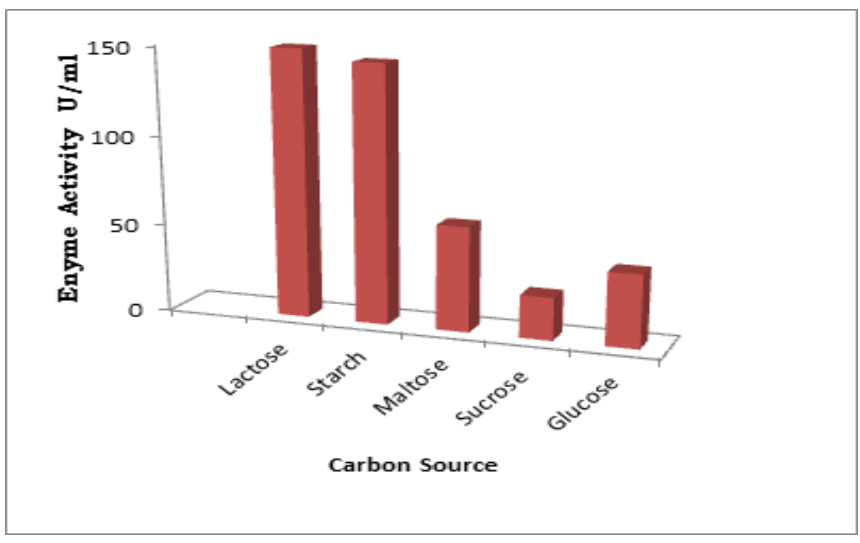

Fig. 6- Effect of different Carbon Source on extracellular lipase by solid submerged fermentation using Bacillus tequilensis, Lactose is high lipase activity

Effect of different Nitrogen Source on extracellular lipase by solid submerged fermentation using Bacillus tequilensis

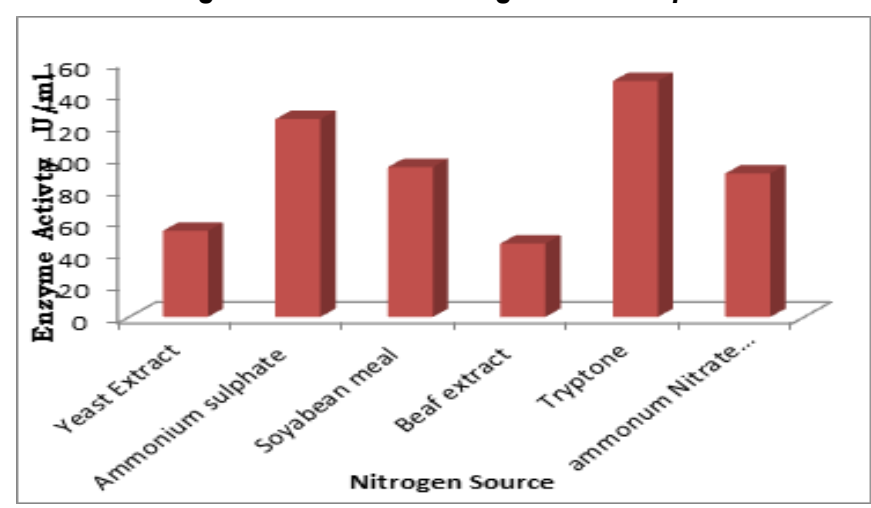

Fig. 7- Effect of different Nitrogen Source on extracellular lipase by solid submerged fermentation using Bacillus tequilensis, tryptone is high lipase activity
Effect of different Oil Source on extracellular lipase by solid submerged fermentation using Bacillus tequilensis

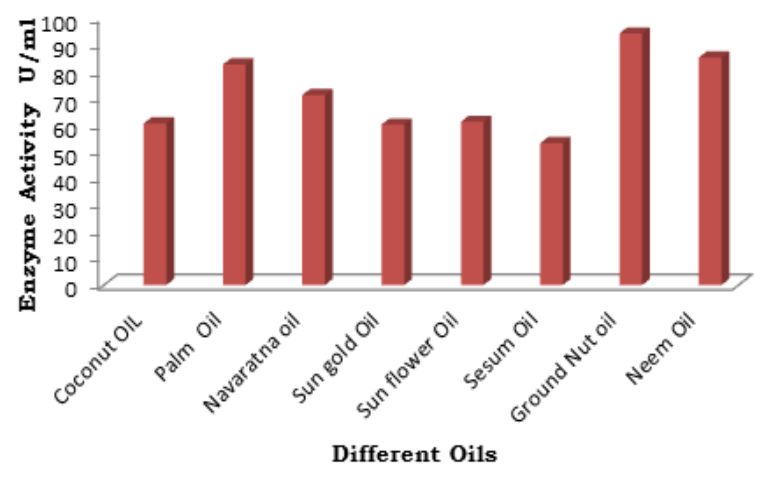

Fig. 8- Effect of different Oil Source on extracellular lipase by solid submerged fermentation using Bacillus tequilensis, Ground nut oil is high lipase activity

\section{Conclusion}

This strain yielded the maximum enzyme activity and the activity of lipase is $150 \mathrm{U} / \mathrm{ml}$ under optimized media conditions as $1 \%$ of Lactose and ground nut oil as the carbon source and Tryptone as the nitrogen source. The optimal cultivating conditions for better yield of Lipase production are 7.0 initial $\mathrm{pH}$ of medium, $30^{\circ} \mathrm{C}$ incubation temperature, $48 \mathrm{hrs}$ incubation periods of seed, $1 \%$ inoculum volume and agitation speed of $200 \mathrm{rpm}$.

\section{Reference}

[1] Tapasys Srivastava, Kynzang Chosdol (2007) Clinical Biochemistry, 3-4.

[2] Veeraragavan K. (1990) Anal Biochem., 186, 301-305.

[3] Thomsan C.A., Delaquis P.J., Mazza G. (1999) Crit. Rev. Food Sci. Nutr., 39, 165-187.

[4] Ashok P., Benjamin S., Soccol C.R., et al. (1999) Biotechnol Appl. Biochem., 29, 119-131.

[5] Falony G., Armas J.C., Mendoza J.C.D., Hernández J.L.M. (2006) Food Technol. Biotechnol., 44, 235-240.

[6] Sharma R., Chisti Y., Banerjee U.C. (2001) Biotechnol. Adv., 19, 627-662.

[7] Gupta R., Gupta N., Rathi P. (2004) Appl. Microbiol. Biotechnol., 64, 763-781.

[8] Priest F.G. (1992) Encyclopedia of Microbiology, Acadamic Press, New York, 2, 8193.

[9] Sierra G. (1957) Mycologia., 71(5), 908.

[10]ACS Specifications (1993) Reagent Chemicals 8th ed., 95

[11]Cardenas J., Alvarez E., de Castro Alvarez M.S., SanchezMontero J.M., Valmaseda M., Elson S.W. and Sinisterra J.V. (2001) Journal of Molecular Catalysis B: Enzyme, 14, 111123.

[12]Musantra A. (1992) Applied Microbiology and Biotechnology, $38,61-66$. 